\title{
Assessment of indicators of fecal contamination in soils treated with biosolids for growing grasses
}

\author{
María Claudia Campos Pinilla ${ }^{1 凶}$, Luz Karime Medina Córdoba ${ }^{1}$, Nancy Piedad Fuentes ${ }^{1}$, \\ Gustavo Ignacio García Montoya ${ }^{2}$
}

\begin{abstract}
Developing countries currently face challenges related to the management and disposal of biosolids that result from wastewater treatment. One of the most important issues they must deal with involves the maximum level of pathogens permitted and the effect they may have on the environment and human health once they are used for agricultural purposes. In order to learn about the risk generated by these kinds of practices, we assessed the behavior of indicators of fecal contamination in grasses used to feed dairy cattle. The study area was divided into two plots: an experimental plot in which diluted biosolids were applied and a control plot without the application of biosolids. We collected samples from soil, grass, surface water and groundwater and analyzed the presence of fecal coliforms, Salmonella spp., somatic phages and helminth eggs. Experimental and control plots showed a decrease in the concentration of bacterial indicators assessed in soil, and low concentrations in surface water, groundwater and grass. Concentrations of viral and parasite indicators tend to decrease more slowly. Our results show that this way of biosolid management allows a better use of its benefits as an organic amendment by lowering the sanitary risk due to the presence of pathogens.
\end{abstract}

Keywords: Biosolids; organic amendment; grasses; pathogens

Edited by Alberto Acosta \& Juan Carlos Salcedo-Reyes

1. Pontificia Universidad Javeriana. Facultad de Ciencias.

Departamento de Microbiología. Bogotá, Colombia.

2 Empresas Públicas de Medellín.

Received: 01-08-2014 Accepted: 09-12-2014

Published on line: 26-02-2015

Citation: Campos Pinilla MC, Medina Córdoba LK, Fuentes NP, García Montoya GI (2015) Assessment of indicators of fecal contamination in soils treated with biosolids for growing grasses. Universitas Scientiarum 20(2): 217-227 doi: 10.11144/Javeriana.SC20-2.aifc

Funding: Pontificia Universidad Javeriana, Empresas Públicas de Medellín.

Electronic supplementary material: N/A

\section{Introduction}

The treatment of domestic wastewater produces organic sludge as a by-product, which is exposed to aerobic or anaerobic treatment for the purpose of stabilizing the organic matter and reducing the pathogen content. This material is known as biosolids and is composed of nutrients, organic matter, metals, organic contaminants and pathogenic microorganisms (EPA 2008).

The high nutrient content of biosolids favors their use as an organic amendment for the improvement of degraded soils, plant cover in sanitary landfills, and agricultural activities such as grass growing (Moss et al. 2002). 
The presence in the biosolids of organic matter with a high content of nitrogen and phosphorous favors their use for agricultural purposes, since they improve the physical and chemical properties of the soil, such as structure, porosity, cation-exchange capacity, and $\mathrm{pH}$. Although the application of biosolids to the land produces benefits, it may also have a negative impact on the soil, surface water, groundwater, food chains and air if carried out in an improper manner. Negative impacts on the water result from an excessive application of nutrients present in the biosolids, which can reach surface and groundwater either by runoff or leaching. Another disadvantage of land application is possible public opposition, which occurs mainly when the application site is located near residential areas and produces unpleasant odors. Finally, the major potential risk is related to the presence of pathogenic microorganisms (bacteria, viruses and parasites) and heavy metals that can be found in significant concentrations even after the stabilization process (Estrada et al. 2004; Forster et al. 2010).

The Part 503 Biosolids Rule of the U.S. Environmental Protection Agency (EPA 2008) establishes the permissible limit of metals and classifies biosolids into Class A and Class B in accordance with the content of pathogenic microorganisms. Class A biosolids have low levels of pathogens, with fecal coliform concentrations $<1 \times 10^{3}$ $\mathrm{CFU} / \mathrm{g}$ TS, Salmonella spp. concentrations $<3 \mathrm{MPN} / 4 \mathrm{~g}$ TS, enteric virus concentrations $<1 \mathrm{PFP} / 4 \mathrm{~g}$ TS, and helminth egg concentrations $<1 / 4 \mathrm{~g}$ TS. This type of biosolids can be used without restrictions. Class B biosolids have fecal coliform levels $>2 \times 10^{6} \mathrm{CFU} / \mathrm{g}$ TS, for which reason restrictions are established at the time of their application.

The survival andinactivation of pathogenic microorganisms in the soil depend on environmental factors, such as precipitation and solar radiation; physicochemical factors, such as soil texture and structure, water flow in the soil (saturated and unsaturated), humidity, temperature, organic matter content and $\mathrm{pH}$; and biological factors, such as the type of microorganism, antagonistic interactions such as predation, competition and the production of inhibitory substances that may reduce their concentration in the soil (Pourcher et al. 2007).

The behavior of pathogenic microorganisms in the soil also depends on whether they are bacteria, viruses or parasites (Forster et al. 2010). Guan \& Holley (2003) found that fecal coliforms survive longer in the soil than Salmonella spp., since they have the ability to withstand adverse environmental conditions such as solar radiation, temperature variations and precipitation. The somatic phages proposed as indicators of viral contamination of fecal origin are prevalent in soils fertilized with biosolids for longer periods of time than are fecal coliforms and Salmonella spp. This resistance appears to be related to the presence of a protein coat or capsid that allows phages to better survive different environmental factors (Gerba et al. 2002).

As for the parasitic indicators, the presence and number of helminths in the biosolids vary with the infection rate prevailing in the community. The presence of Ascaris, Trichuris, Taenia and Toxocara in biosolids is common, with Ascaris being the most common and resistant of the helminths. Ascaris eggs are resistant to adverse environmental conditions and remain infective for several years (Schwartzbrod \& Banas 2003).

Microorganisms in the soil can reach water by transport mechanisms that depend on factors such as changes in water flow and cell motility. Therefore, the course followed by water, whether infiltration or surface runoff, determines the direction of movement of the bacteria (Bitton \& Harvey 1992).

Grass can become contaminated by direct contact with biosolids, as pathogens cannot be absorbed by the root system of plants, except when there is an alteration in the plant that allows for the penetration of the microorganism. The survival of microorganisms is often lower in plants than in the soil, because in plants they are inactivated by sunlight, desiccation, temperature, and antimicrobial agents produced by the plant (Okafo et al. 2003).

The aim of this study is to evaluate the behavior of pathogens present in biosolids applied as an organic amendment to a grass crop to be used as feed for dairy cattle.

\section{Materials and methods}

The biosolids used in this study come from the San Fernando wastewater treatment plant located in the municipality of Itagüi (Antioquia, Colombia). The system has a nominal capacity of $1.8 \mathrm{~m}^{3} / \mathrm{s}$ and currently treats an 
average of $1.35 \mathrm{~m}^{3} / \mathrm{s}$, of which $65 \%$ is from households and $35 \%$ is of industrial origin. The wastewater is treated by means of activated sludges, which remove $80 \%$ of the contamination represented by BOD and TSS. The resulting sludge is stabilized after treatment by a mesophilic anaerobic digestion process followed by centrifugal dehydration until $38 \%$ dryness is achieved. This process produces $80 \mathrm{t} / \mathrm{d}$ of biosolids.

The biosolids generated in the San Fernando plant are classified as Class B biosolids in accordance with the EPA's Part 503 Biosolids, as they exceed the concentrations of pathogens allowed for Class A biosolids (fecal coliforms 2.6x10 CFU/g TS, Salmonella spp. 0.55 MPN/4 g TS, viable helminth eggs $12 \mathrm{VHE} / 4 \mathrm{~g}$ TS, and somatic phages $3.1 \times 10^{3}$ $\mathrm{PFP} / \mathrm{g}$ TS, used as indicators of enterovirus presence). Concentrations of heavy metals (arsenic, copper, cadmium, chromium, mercury, molybdenum, nickel, lead, zinc, and selenium) are below the limits suggested by Part 503 .

Study area: This study was conducted in the municipality of Entrerríos located in the north of the Department of Antioquia in Colombia. Dairy farming is the predominant activity in the area, with a production of about 450,000 liters of milk per day, hence the need for a constant production of good quality pasture. For this reason, chemical fertilizers and chicken or pig manure are applied. An alternative to the use of these products is the application of biosolids, whose concentration of nutrients can produce increased crop yields (EPA 2008).

The study area is located on a dairy farm in which two plots with similar characteristics were delimited. One of them had received biosolids for more than 3 years and hence was designated the experimental plot, and the other one had received applications of urea as a fertilizer, but no biosolids, and was therefore designated the control plot. The two plots have the same physiographic components in terms of slope, soil and water sources. The soils developed on reworked volcanic ash, have a granular structure and clay-loam texture, and their depth ranges from 10 to 30 $\mathrm{cm}$ depending on the degree of erosion. They have a slope of $5 \%$ at the upper part, $15-25 \%$ in the middle part, and $5-8 \%$ in the lower part. The experimental plot has a surface area of $1.4 \mathrm{ha}$, and the control plot has a surface area of 0.5 ha. The superficial water source is located at the plot lower part and goes first to the control plot continuing with the experimental plot (Figure 1 and 2).

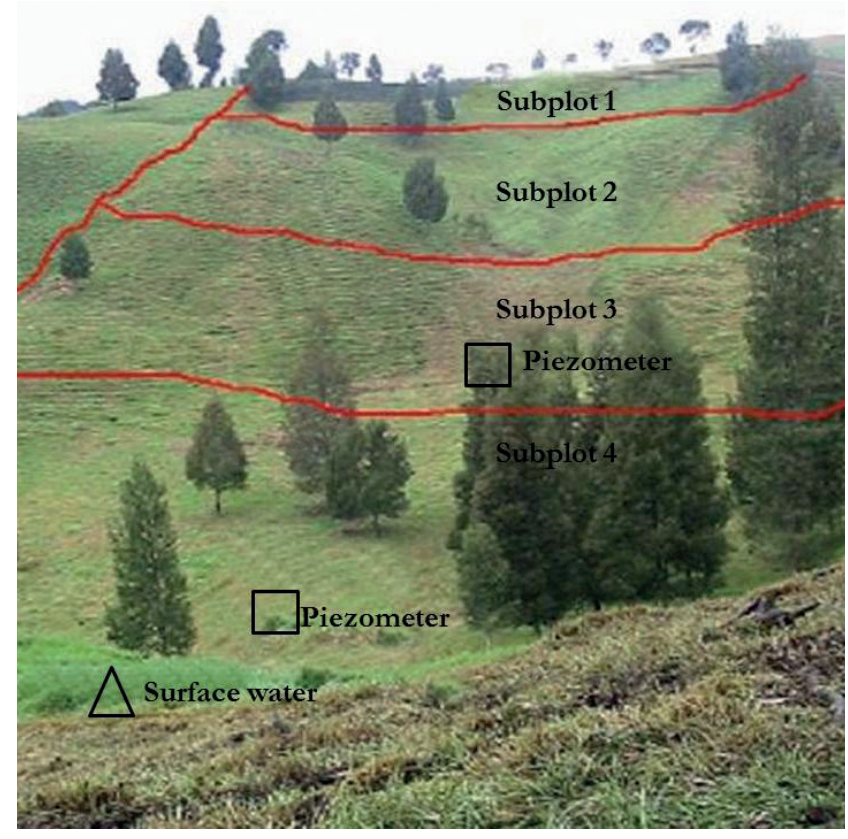

Fig. 1. Distribution of the experimental plots and location of the piezometers and surface water.

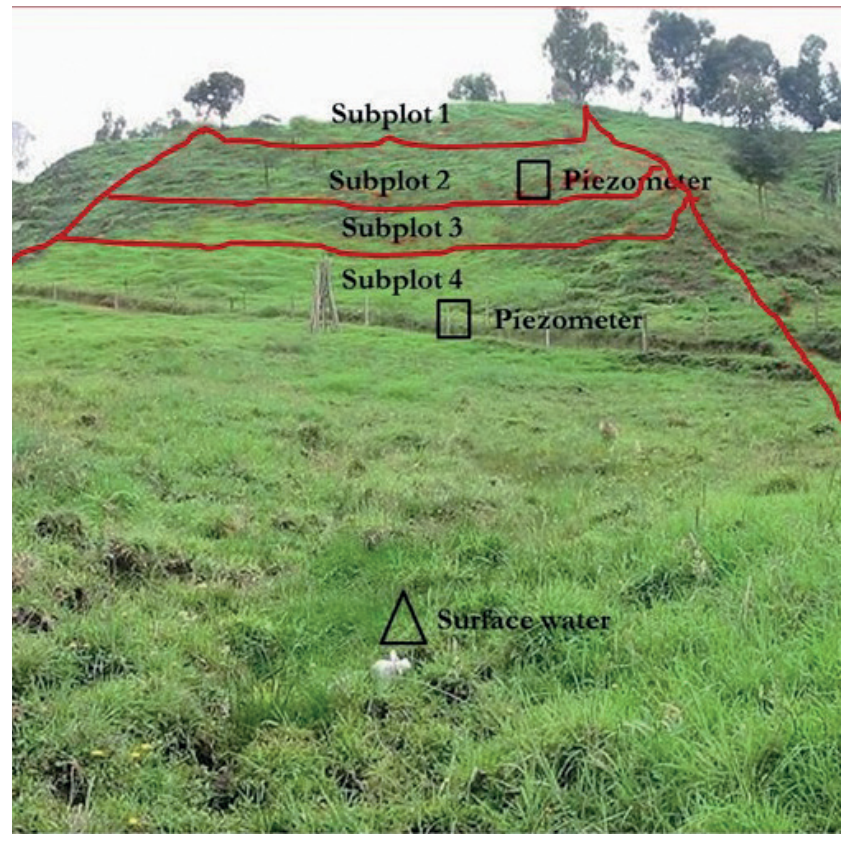

Fig. 2. Distribution of the control plots and location of the piezometers and surface water. 
Besides the assessment of pathogen behavior in the plot receiving biosolids as organic amendment, and compared with plots using different types of fertilizers, the soil productivity was evaluated through agronomic parameters compared with traditional fertilizers. These results are in Zapata et al. 2011.

For the groundwater sampling, two piezometers were installed in the experimental plot and two in the control plot, at a depth of $1.0 \mathrm{~m}$ in the middle part of the slope and $0.5 \mathrm{~m}$ in the lower part. The surface water was collected from a water channel that was located in the lowest part of each of the plots. The biosolids were diluted to $95 \%$ in water from a stream near to the disposal site material, until they became liquid to facilitate their manual application by means of a hose. Previously, the water was analyzed and no target microorganisms were found. This process recovered up to 80 or $90 \%$ of the moisture. After 45 days the grass was high enough for the cattle to graze, and once the cattle finished they moved to another plot. After the removal of the cattle, a new application of biosolids was begun. The cycle for the control plot was the same, but with application of urea.

Each plot was divided into four subplots: A, B, C and D. Soil, groundwater (two piezometers at each plot), surface water (localized at the lower part of each plot) and grass were sampled in each subplot. Samples were taken 24 hours after the application of biosolids, designated as time zero, and after 15, 30 and 45 days. The sampling was repeated over 3 cycles with identical characteristics. In the case of the control plot, samples were taken only at time zero and after 45 days, since low concentrations of microorganisms were expected in absence of fecal contamination source.

To analyze the presence and concentration of microorganisms in the soil, composite samples were taken at a depth of $10 \mathrm{~cm}$ with the aid of a soil borer following a z-shaped path. Collected samples were mixed together and placed inside hermetically sealed bags. Groundwater was collected from the piezometers by manual pumping, and surface water was sampled directly from the channel. There was a sufficient volume of surface water to analyze the helminth eggs, but it was not possible to collect the water volume required for this analysis from the piezometers on each sampling day. In some cases there were insufficient samples for analyzing bacteria and phages because the volume found in the piezometers varied depending on the number of rainy days. On day 45 , before the cattle entered to graze, grass samples were analyzed to determine the concentration of pathogens. The samples were taken at random by cutting the top of the grass, which is what is usually consumed by the cattle, and storing it in hermetically sealed bags. The samples were transported inside Styrofoam coolers with dry ice, maintained at a temperature of $4^{\circ} \mathrm{C}$ and processed within 48 hours from the time of collection.

The microorganisms assessed in each of the study matrices were fecal coliforms and Salmonella spp. as bacterial indicators; somatic phages, as viral indicators; and helminth eggs, as parasitic indicators.

We used the following protocols for the analysis of microorganisms (a) in soil and biosolids: fecal coliforms (EPA 625/R-92/013 2003), Salmonella spp. (1682 EPA-821-R-06-014 2006), somatic phages (Lasobras et al. 1999 and ISO 10705-2 1999) and helminth eggs (NOM-004 2002); (b) in water: fecal coliforms (APHA 9222 2005), Salmonella spp. (APHA 9260-B 2005), somatic phages (ISO 10705-2 1999) and helminth eggs (NMX-AA-113-SCFI 1999); and (c) in grasses: fecal coliforms (EPA 625/R-92/013 2003) and Salmonella spp. (1682 EPA-821-R-06-014 2006) (for these two microorganisms we followed the same protocol as for biosolids, but with a weight of 30 grams of fresh grass), somatic phages (Dubois et al. 2006 and ISO 10705-2 1999) and helminth eggs (Kozan et al. 2005 and NOM-004 2002).

Statiscal analysis: The statistical analysis was carried out using SPSS (2011), by running normality tests and analyses of variance (ANOVA) to determine whether there are significant differences in the concentration of microbial indicators in each of the cycles evaluated. We used a significance level of 0.05 .

\section{Results}

The average concentration of microorganisms found in the biosolids and diluted biosolids is shown in Table 1. 
Table 1. Concentration of fecal coliforms, Salmonella spp., somatic phages, and helminth eggs in the biosolids and diluted biosolids. CFU: Colony Forming Units. MPN: Most Probable Number. PFP: Plaque-Forming Particles. VHE: Viable Helminth Eggs. TS: Total Solids.

\begin{tabular}{lcc}
\hline \multicolumn{1}{c}{ Indicator } & Biosolids & $\begin{array}{c}\text { Diluted } \\
\text { Biosolids }\end{array}$ \\
\hline Fecal coliforms CFU/gTS & $2.6 \times 10^{5}$ & $8.6 \times 10^{6}$ \\
Salmonella spp MPN/4 g TS & $<0.56$ & $<0.67$ \\
Somatic phages PFP/4g TS & $3.1 \times 10^{3}$ & $7.3 \times 10^{3}$ \\
Helminth eggs VHE/4g TS & 12 & 10 \\
\hline
\end{tabular}

There were no significant differences between the concentration of fecal contamination indicators in biosolids and diluted biosolids during the three sampling cycles $(p>0.05)$.

The average results obtained in the experimental plot during the three sampling cycles are shown in Tables 2, 3, and 4. Results for day 15 and 30 in the case of soil in experimental plot are not included because they have concentrations in the same magnitude order as time zero without significant differences.

Table 2. Average concentrations of fecal coliforms, Salmonella spp., somatic phages, and helminth eggs in soils of the experimental plot. CFU: Colony Forming Units. MPN: Most Probable Number. PFP: Plaque-Forming Particles. VHE: Viable Helminth Eggs. TS: Total Solids. T0: 24 hours after biosolid application. T45: 45 days after biosolid application. <: Less than the quantification limit of the technique.

\begin{tabular}{|c|c|c|c|c|c|c|c|c|}
\hline 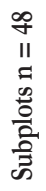 & 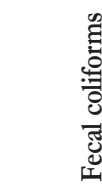 & & 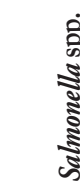 & 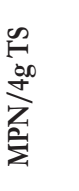 & u & 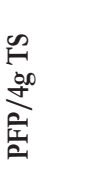 & 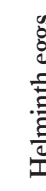 & $\begin{array}{l}\stackrel{0}{1} \\
\stackrel{\infty}{+\infty} \\
\frac{1}{+} \\
\frac{1}{5}\end{array}$ \\
\hline & T0 & T45 & T0 & T45 & T0 & T45 & T0 & $\mathrm{T} 45$ \\
\hline A & $1.7 \times 10^{3}$ & $4.6 \times 10^{2}$ & $<0.54$ & $<0.43$ & $2.2 \times 10^{2}$ & $1.3 \times 10^{2}$ & 3.3 & 1.2 \\
\hline B & $6.3 \times 10^{3}$ & $1.6 \times 10^{2}$ & $<0.51$ & $<0.44$ & $1.9 \times 10^{2}$ & $1.1 \times 10^{2}$ & 2.0 & 1.3 \\
\hline C & $2.1 \times 10^{4}$ & $7.4 \times 10^{2}$ & $<0.52$ & $<0.42$ & $3.4 \times 10^{2}$ & $1.1 \times 10^{2}$ & 2.0 & 1.7 \\
\hline $\mathrm{D}$ & $5.7 \times 10^{4}$ & $2.1 \times 10^{2}$ & $<0.46$ & $<0.41$ & $4.9 \times 10^{2}$ & $1.1 \times 10^{2}$ & 2.4 & 1.7 \\
\hline
\end{tabular}

As seen in the results of the analysis of microorganisms in the soil of the experimental plot in Table 2, the concentration of fecal coliforms to 24 hours after the biosolids application was reduced by between two and three orders of magnitude at time zero respect to the concentration in the biosolids, and between one and two orders of magnitude 45 days after the application, showing significant differences $(p<0.05)$. Salmonella spp. remained below the quantification limit of the technique. The concentration of somatic phages decreased by one order of magnitude when the biosolids were applied to the soil and it remained unchanged during the evaluation period, with no significant differences ( $p>0.05)$. Helminth eggs were reduced when the biosolids were applied to the soil and after 45 days of assessment, but this reduction was not significant ( $p>0.05)$.

Table 3. Average concentrations of fecal coliforms, Salmonella spp., somatic phages, and helminth eggs in surface and groundwater in the experimental plot. ND: Not Determined.

\begin{tabular}{|c|c|c|c|c|}
\hline $\begin{array}{l}\mathrm{n}=11 \text { (Surface) } \\
\mathrm{n}=4 \quad \text { (Piezometer } 1) \\
\mathrm{n}=13 \text { (Piezometer } 2)\end{array}$ & 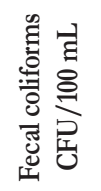 & 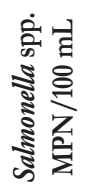 & 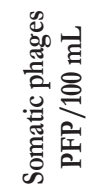 & 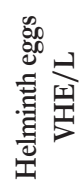 \\
\hline Surface & $2.1 \times 10^{2}$ & $<1.8$ & $9.0 \times 10^{1}$ & $<0.1$ \\
\hline Piezometer 1 & $2.5 \times 10^{1}$ & $<1.8$ & $1.6 \times 10^{3}$ & ND \\
\hline Piezometer 2 & $1.7 \times 10^{2}$ & $<1.8$ & $1.3 \times 10^{1}$ & ND \\
\hline
\end{tabular}

Table 3 shows average results from the days when enough water volume was collected for the analysis. The average concentrations of fecal coliforms in surface water was $10^{2}$ to $10^{1}$ for somatic phages, and below the quantification limit for Salmonella spp. and helminth eggs. The results are similar in the case of groundwater, except for Piezometer 1, in which the concentration of somatic phages was 1.6x $10^{3}$. Sampling was carryout on day 0, 15, 30 and 45. However only in some cases the water could be collected. Consequently, it was decided to average the water volume from the places were the water sample could be attained. 
Table 4. Average concentrations of fecal coliforms, Salmonella spp., somatic phages and helminth eggs on the grasses of the experimental plot. FW: Fresh Weight.

\begin{tabular}{|c|c|c|c|c|}
\hline $\begin{array}{l}\approx \\
\text { II } \\
\text { 11 } \\
0 \\
0 \\
\frac{0}{2} \\
\frac{0}{2} \\
\text { के }\end{array}$ & 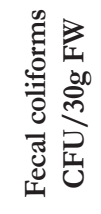 & 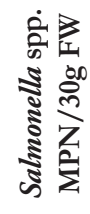 & 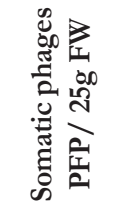 & 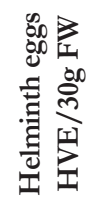 \\
\hline A & $3.5 \times 10^{2}$ & $<0.06$ & $2.0 \times 10^{2}$ & 1.3 \\
\hline B & $2.3 \times 10^{1}$ & $<0.06$ & $1.0 \times 10^{2}$ & 1.6 \\
\hline $\mathrm{C}$ & $1.2 \times 10^{2}$ & $<0.06$ & $1.7 \times 10^{1}$ & 1.2 \\
\hline $\mathrm{D}$ & $5.0 \times 10^{2}$ & $<0.06$ & $9.4 \times 101$ & 1.9 \\
\hline
\end{tabular}

Table 4 shows concentrations between $10^{1}$ and $10^{2}$ for fecal coliforms and somatic phages, values below the limit of quantification for Salmonella spp., and 1.3 to 1.9 helminth eggs. The source of these organisms is the biosolids applied to the soil, which came into contact with the grass as it grew.

The average concentrations of fecal coliforms, Salmonella spp., somatic phages and helminth eggs in the soil, groundwater and surface water of the control plot are shown in Tables $\mathbf{5}$ and $\mathbf{6}$.

Table 5. Average concentrations of fecal coliforms, Salmonella spp., somatic phages and helminth eggs in soils of the control plot.

\begin{tabular}{|c|c|c|c|c|c|c|c|c|}
\hline 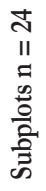 & 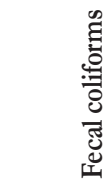 & 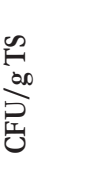 & 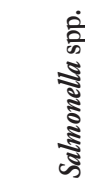 & 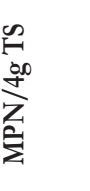 & $\mathscr{Z}$ & 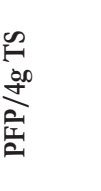 & 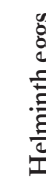 & 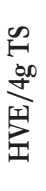 \\
\hline & T0 & T45 & T0 & T45 & T0 & T45 & T0 & T45 \\
\hline A & $2.1 \times 10^{3}$ & $1.9 \times 10^{2}$ & $<0.42$ & $<0.39$ & $6.6 \times 10^{1}$ & $6.2 \times 10^{1}$ & 0.6 & 1.0 \\
\hline B & $2.0 \times 10^{2}$ & $2.9 \times 10^{2}$ & $<0.45$ & $<0.38$ & $7.2 \times 10^{1}$ & $6.2 \times 10^{1}$ & 0.6 & 0.4 \\
\hline C & $3.6 \times 10^{2}$ & $6.6 \times 10^{1}$ & $<0.50$ & $<0.43$ & $7.8 \times 10^{1}$ & $6.7 \times 10^{1}$ & 0.5 & 0.8 \\
\hline $\mathrm{D}$ & $3.4 \times 10^{1}$ & $2.3 \times 10^{1}$ & $<0.48$ & $<0.40$ & $7.4 \times 10^{1}$ & $6.3 \times 10^{1}$ & 0.4 & 0.5 \\
\hline
\end{tabular}

The initial concentration of fecal coliforms ranged from $10^{1}$ to $10^{3} \mathrm{CFU} / \mathrm{g}$ TS, with a decrease of one order of magnitude in subplots $\mathrm{A}$ and $\mathrm{C}$. The values for Salmonella spp. were below the quantification limit of the technique. The concentration of somatic phages was $10^{1}$ and there were between 0.5 and 1 VHE from both human and animal origin. There were no significant differences in the reduction of fecal contamination indicators during the evaluation period in the control plot ( $p>0.05)$. The origin of this contamination may be related to the passage of animals through the plot, where remains of horse and dog manure were found at the time of sampling. This type of waste was not seen in the experimental plot.

Table 6. Average concentrations of fecal coliforms, Salmonella spp., somatic phages, and helminth eggs in surface water and groundwater in the control plot. ND: Not Determined.

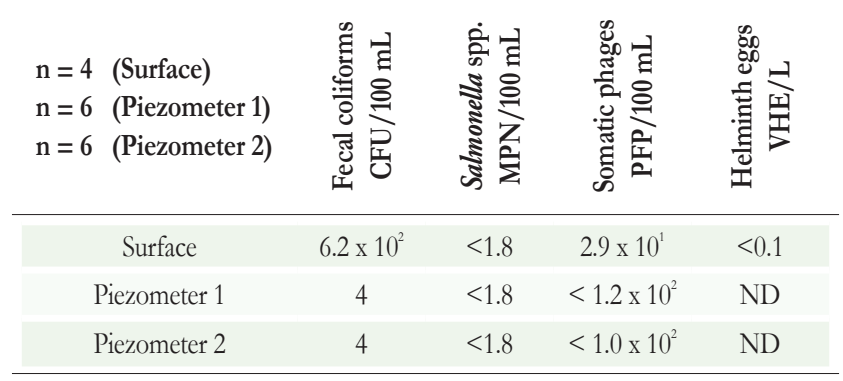

In the case of surface water, concentrations of fecal coliforms and somatic phages were $10^{1}$. Salmonella spp. and helminth eggs were below the quantification limit of the technique. The concentrations are lower than in the experimental plot because, although there was animal manure, there was no contact with a permanent and uniform source of microbial contamination. In the case of groundwater, very low concentrations or concentrations below the quantification limit of the technique were observed, and a sufficient volume of water to process helminth eggs was not obtained. The concentrations of fecal coliforms, Salmonella spp., somatic phages and helminth eggs in grasses were in all the cases below the limit of quantification of the technique. 


\section{Discussion}

The analysis of the concentration of fecal contamination indicators, such as fecal coliforms, Salmonella spp., somatic phages and helminth eggs, is necessary in order to characterize the sanitary risks associated with the use of biosolids as organic amendment in agriculture (Forster et al. 2010). The risk in this case is related to the presence of pathogens in soil, groundwater, surface water and grass.

The sludge resulting from wastewater treatment is stabilized by means of aerobic or anaerobic treatments, which do not guarantee the elimination of pathogens. The mesophilic anaerobic treatment used in this study produces biosolids with high concentrations of pathogens; hence the biosolids must be applied with constraints related to soil type, season and distance from sources of surface water or groundwater (EPA 2003). Forster et al. (2010) found, in a study conducted in northern Spain, that after the mesophilic anaerobic stabilization treatment of the sewage sludge, detectable levels of microorganisms such as fecal coliforms and Salmonella spp. were still present at concentrations of $4 \times 10^{4} \mathrm{CFU} / \mathrm{g}$ TS and 1.27 MPN/4 g TS, respectively.

In relation to viruses, Gerba et al. (2002) found that the process of anaerobic digestion of sludge is not effective in lowering the presence of enteroviruses, and that these viruses can survive as infectious particles for prolonged periods of time. Sidhu et al. (2008) indicate that the number of enteric viruses in raw and digested biosolids varies widely. They reported concentrations ranging from $10^{3}$ to $10^{9}$, possibly due to weather conditions and periods of rain or drought in each study site.

Schwartzbrod \& Banas (2003), in an evaluation of sludge from two wastewater treatment plants in France, observed survival times of 20 months up to 6 years for Ascaris eggs after mesophilic anaerobic digestion.

Soil-borne pathogens: Once the biosolids were applied to the soil, there was a decrease of up to three orders of magnitude in pathogens, which may have occurred due to the biosolids mixture with the soil inducing a dilution effect and the change in environmental factors once microorganisms reached this matrix. Moisture content from the samples taken in the the soil was $65 \%$, average temperature was $20^{\circ} \mathrm{C}$, and there were periods of rain and drought that affected the presence of microorganisms. However, the decrease at day 45 is smaller and has no important variations. These results agree with those obtained by Avery et al. (2004) when assessing the prevalence of fecal coliforms in soils to which animal manure had been applied in the summer and winter. Our results suggest that the survival of fecal coliforms in the soil depends on periods of rain and soil moisture conditions, since with a moisture content of $85 \%$ concentrations were $>10^{7}$, while in dry periods we found concentrations of $10^{2}$ and $10^{3} / \mathrm{g}$. Similarly, at a relative humidity of $76 \%$ and temperature of $25{ }^{\circ} \mathrm{C}$, Estrada et al. (2004) observed fecal coliform survival up to 40 days after application to the soil. Besides these two factors, the influence of solar radiation, rainfall, soil texture and structure, organic matter content and $\mathrm{pH}$, as well as the presence of antagonistic and inhibitory substance producing microorganisms, are regarded as important (Pourcher et al. 2007).

Salmonella spp. are commonly isolated from raw and anaerobically treated sludge in relatively low numbers (1-52/g of dry weight) compared to fecal coliforms, which are found at higher concentrations $\left(10^{5}\right.$ to $10^{6} / \mathrm{g}$ of dry weight) (Sahlstromet et al. 2004). Data found for the concentration of Salmonella spp. in our study was under the detection limits. However, studies by Parmar et al. (2001) found concentrations of Salmonella spp. of up to $10^{7} \mathrm{CFU} / \mathrm{mL}$ in anaerobically digested biosolids.

Zaleski et al. (2005), compared the presence of Salmonella spp. in stored biosolids before and after they were applied to the soil, and observed permanence periods of up to three months, possibly due to a regrowth process, while once applied to the soil their survival period decreased to one month due to the influence of environmental factors.

In our study, somatic phages remained at similar concentrations during the 45 days, showing greater resistance than bacteria. Pourcher et al. (2007) compared the behavior of bacteria and somatic phages in soil after the application of liquid manure, noting that the survival of phages is much longer (143 days of permanence) than that of Salmonella spp. and fecal coliforms which were not detected after 10 days. 
Cárdenas et al. (2009) found permanence times of somatic phages of up to 120 days in biosolid-amended soils used for growing grass. This survival is linked to structural and morphological characteristics that make them more resistant to environmental factors.

Schwartzbrod \& Banas (2003) observed a permanence of helminth eggs of up to 200 days in soils. This was possible because the survival of helminths varies considerably depending on factors such as moisture and temperature, although they are generally more resistant than bacteria and viruses. The presence and number of helminths in biosolids can vary depending on the prevailing rate of infection in the community. In digested biosolids, the presence of Ascaris, Trichuris, Taenia and Toxocara varies from 0 to 9 eggs/ g of dry weight, with Ascaris being the most common. In our study, the presence of viable eggs in the biosolids, ranges from 0.6 to 3.3 and Ascaris eggs were found in greater proportions than those of other helminths. Ascaris eggs are resistant to environmental conditions and can remain infective for several years. Also found that the eggs of Ascaris lumbricoides are more frequent than the eggs of Ancylostoma and Hymenolepis diminuta. Furthermore, they detected viable eggs of Toxocara, Capillaria and Trichuris as well as Ascaris eggs in the digested sludge (0.25 to $7 / \mathrm{g}$ of dry weight) of 20 wastewater treatment plants in France.

Jiménez et al. (2000) found concentrations of Ascaris of between 66 and 136/g in biosolids in Mexico City, probably due to an increased incidence of helminth infection in the population. According to studies by Cárdenas et al. (2009) in Colombia, the average concentrations of these parasites in soils receiving biosolids for growing grass is $21 \mathrm{VHE} / 4 \mathrm{~g}$ TS four months after application.

After 45 days of application of the diluted biosolids our study found that bacterial, viral and parasitic indicators were present evidencing permanence during long periods of time. However, when the concentrations are compared with the suggested by EPA for a Class A biosolids, we can consider that the health risk decreases as the fecal coliform count approaches to $1000 \mathrm{CFU} / \mathrm{g}$ ST, Salmonella spp. $<3 \mathrm{MPN} / 4 \mathrm{~g}$, helminth eggs $<1 \mathrm{VHE} / 4 \mathrm{~g}$ of ST and somatic phages under <50000 PFP/4g ST (MVCT 2014).
Waters: As a result of the use of organic amendment for agricultural purposes, pathogenic microorganisms can be transported to water bodies during periods of rain and runoff, creating risks for the population that uses them as a source of consumption. In our study, the analysis of surface water in both plots revealed maximum concentrations of $10^{2} / \mathrm{mL}$ of fecal coliforms and somatic phages. While these are not high concentrations, they highlight the risk of contamination of matrices other than soil, especially on sloping terrain. The concentrations of Salmonella spp. and helminth eggs in these waters were below the quantification limit of the technique.

Enteric microorganisms that reach surface waters encounter a hostile environment that may directly or indirectly cause cell death or sub-lethal damage. There are factors such as solar radiation, $\mathrm{pH}$, humic substances, predation, adsorption, sedimentation and salinity that determine the presence of pathogens in the water. George et al. (2001) studied the behavior of fecal coliforms in water and found that their prevalence depends on the physical attachment of these microorganisms to the suspended matter, because the greater the organic matter content, the higher the concentration of microorganisms. In the case of enteric viruses, survival times in surface waters have been longer than those recorded for bacteria (Huw 2003).

In the groundwater of the two plots, the concentration of fecal coliforms and somatic phages ranged from $10^{1}$ to $10^{2} / \mathrm{mL}$. The permanence of these microorganisms in the soil and theirsubsequent transportto groundwater depends on a number of mechanisms for removing bacteria, viruses and parasites from the soil, which are related to the source of contamination of soil and groundwater. It is known that microorganisms from water or sludge that come into contact with the soil can be transported or removed through mechanisms that influence the transport and removal of viruses and bacteria, such as dispersion, adsorption, filtration and death. The two mechanisms that significantly influence the elimination of microorganisms in the subsurface of the soil are survival and movement. These two mechanisms should be considered when there is a risk of groundwater pollution by pathogenic microorganisms (Bitton \& Harvey 1992). 
Grasses: The concentrations of pathogens in grasses are similar to those found by Cárdenas et al. (2009) in similar weather conditions, but in plots where sludge was applied directly to the soil without dilution the average fecal coliform concentrations were $10^{3}$ $\mathrm{CFU} / 30 \mathrm{~g}$ of fresh weight, and the concentrations of somatic phages and helminth eggs were below the quantification limit of the technique. The World Health Organization (2006) has established that the concentration of fecal coliforms and Salmonella spp. in agricultural products such as vegetables, lettuce or any other crop grown for making salads for human consumption must be less than $10^{3} \mathrm{CFU} / \mathrm{g}$ if it is not to pose a risk to human health. Although this is a human health-related datum, it was used to attempt to establish a possible risk of infection of cattle caused by the consumption of grass contaminated by human fecal pathogens. Based on this premise, the risk from grass consumption would be low because the fecal coliform concentration was below this limit.

The permanence of fecal coliforms 45 days after the application of biosolids coincides with the findings of Ogden et al. (2002) in pastures that could be isolated for up to 6 months after the application of manure. As expected, all of the indicators in the control plot were below the quantification limit of the technique, as no biosolids were applied, and contamination by animal fecal sources does not seem to have influenced the microbiological quality of the grasses.

The main source of microbial contamination of vegetables grown with organic fertilizers is fecal coliforms, and the reported counts are between $2.6 \times 10^{3}-2.5 \times 10^{4}$. The survival of microbial pathogens on plants is often less than that observed in soil, and this is mainly due to inactivation by sunlight, desiccation and temperature changes. The production of enzymes or antimicrobial compounds through a plant's roots serves as a barrier to prevent the entry of pathogens. When pathogens reach a plant's surface they come into contact with organic acids and other natural antimicrobial substances present in the fluids of plant tissues. However, when cell breakage is caused by mosquitoes or other insects, infection is favored (Okafo et al. 2003).

Comparing the results from the plots, we observed that the biosolids introduced fecal origin microorganisms into the different matrices, which are reduced over time under the environmental factors influence. In the control plot where chemical fertilizers are used, the concentration of microorganisms is less and is originated by the manure of animals passing through the plots. The advantage of the use of biosolids compared to traditionally used fertilizers is the increase in crop production although is necessary rigorous monitoring of the sanitary risk (Zapata, 2011).

\section{Conclusion}

Forty-five days following the application of biosolids to the soil in the experimental plot, the concentration of fecal contamination indicators were low and close to the suggested for a biosolids Class A. Although the concentration of pathogens in surface and groundwater are not very high, the presence of these microorganisms in water sources is a warning sign of a possible risk of aquifer contamination from the application of this amendment. We found low concentrations of microorganisms in grasses, suggesting that there is a minimal health risk for their consumption by animals. In the control plot were no biosolids are applied, the indicators concentrations were below the quantitation limit, offering no risk of pathogen transmission to the livestock. The low fecal contamination comes from animals passing the area.

\section{Acknowledgements}

Empresas Públicas de Medellín and Pontificia Universidad Javeriana provided technical and financial support for this research.

\section{Conflicts of interest}

The authors agree with the results published in this article and state that there are not conflicts of interest.

\section{References}

American Public Health Association (2005) Standard methods for examination of water and wastewater. $20^{\text {th }}$ ed. American Public Health Association/American Water Works Association/Water Environment Federation. Washington, D.C., United States, 321 
Avery S, Moore A, Hurchison ML (2004) Fate of Escherichia coli originating from livestock faeces deposited directly onto pasture. Letter Applied Microbiology, 38: 355- 369

Bitton G, Harvey R (1992) Transport of pathogens through soils and aquifers. In Environmental Microbiology. $19^{\text {th }}$ ed. by Ralph Mitchell. New York, USA, 103-123

Cárdenas M, Moreno G, Campos C (2009) Evaluation of fecal contamination indicators (fecal coliforms, somatic phages, and helminth eggs) in ryegrass sward farming. Journal of Environmental Science and Health, Part A. 44: 249-257

Dubois E, Hennechart C, Deboosere N, Merle G, Legeay O, Burger C, Le Calvé M, Lombard B, Ferré V, Traeré, O (2006) Intra-laboratory validation of a concentration method adapted for the enumeration of infectious F-specific RNA coliphage, and hepatitis A virus from inoculated leaves of salad vegetables. International Journal of Food Microbiology 108: 164-171

Environmental Protection Agency (EPA) (2003) Biosolids generation, use, and disposal in the United States. EPA 530-R-99-009. USA, 74

Environmental Protection Agency (EPA) (2006) Method 1682: Salmonella in Sewage Sludge (Biosolids) by Modified Semisolid Rappaport-Vassiliadis (MSRV) Medium. 1682 EPA - 821-R-06-014. 2006. USA, 41

Environmental Protection Agency (EPA) (2008) Biosolids Technology Fact Sheet. Use of Landfilling for Biosolids Management. USA, 103

Estrada I, Aller A, Aller F, Gómez X, Morán A (2004) The survival of Escherichia coli, faecal coliforms and enterobacteriaceae in general in soil treated with sludge from wastewater treatment plants. Bioresource Technology. 93: 191-198

Forster T, Riau V, Perez M (2010) Mesophilic anaerobic digestion of sewage sludge to obtain class B biosolids: Microbiological methods development. Biomass and Bioenergy 34: 1805-1812

Gerba CP, Pepper IL, Whitehead III LF (2002) A risk assessment of emerging pathogens of concern in the land application of biosolids. Water Science and Technology 46: $225-30$

George AI, George M, Petit C (2001) Theate and P. Servais, Distribution of coliforms in the Scine River and estuary (France) studies by enzymatic methods and plate counts. Estuaries 24: 994-1002

Guan TY, Holley RA (2003) Pathogen survival in swine manure environments and transmission of human enteric illness: a review. Journal of Environmental Quality 32: 383-392

Huw T (2003) Surface Waters. School of Environment University of Brighton, BN2 4 GJ, UK, 32-39
International Standard Organization (1999) Water Quality - Detection and enumeration of Bacteriophages. Part 2: Enumeration of Somatic Coliphages. ISO 10705, 2 - 17

Jimenez B, Barrios JA, Maya C (2000) Class B biosolids production from wastewater sludge with high pathogenic content generated in an advanced primary treatment. Water Science and Tecbnology 42: 103-10

Kozan E, Gonenc B, Sarimehmetoglu O, Aycicek H (2005) Prevalence of helminth eggs on raw vegetables used for salads. Food Control 16: 239 - 242

Lasobras J, Dellunde J, Jofre J, Lucena F (1999) Occurrence and levels of phages proposed as surrogate indicators viruses in different types of sludges. Journal of Applied Microbiology 86: 723-729

Ministerio de Vivienda, Ciudad y Territorio. Decreto 1287 (2014). Criterios para el uso de biosólidos generados en plantas de tratamiento en aguas residuales municipales. Colombia, 15

Moss LH, Epstein E, Logan T (2002) Evaluating risk and benefits of soil amendments used in Agriculture. Water Environmental Research Foundation and IWA Publishing. USA, 1-5

Norma Oficial Mexicana. NMXM-AA-113-SCFI- (1999). Determinación y cuantificación de huevos de helminto por técnica EPA. USA, 25

Norma Oficial Mexicana. NOM-004-ECOL- (2002) Lodos y biosólidos. Especificaciones y límites máximos permisibles de contaminantes para su aprovechamiento y disposición. México, 61

Okafo C, Umoh V, Galadima M (2003) Occurrence of pathogens on vegetables harvested from soils irrigated with contaminated streams. Science of The Total Environment. 311: 49-56

Ogden I, Hepburn N, MacRae M, Strachan N, Fenlon D, Rusbridge S, Longterm A, (2002). Survival of Escherichia coli O157 on pasture following an outbreak associated with sheep at a scout camp. Letter Applied Microbiology. 34: 224-229.

Parmar N, Singh A, Ward P (2001) Characterization of the combined effect of enzymes, $\mathrm{pH}$ and temperature for removal of pathogens from sewage sludge. World Journal of Microbiology and Biotechnology 17:169-172

Pourcher A, Bonnaud P, Oise F, Virginie F (2007) Survival of faecal indicators and enteroviruses in soil after landspreading of municipal sewage sludge. Applied Soil Ecology 35: 473-479

Sahlstromet L, Aspa A, Bagge E, Tham MLD, Albihn A (2004) Bacterial pathogen incidences in sludge from Swedish sewage treatment plants. Water Resources 38: 1989-94 
Schwartzbrod J, Banas S (2003) Parasite contamination of liquid sludge from urban wastewater treatment plants. Water Science and Technology 47:163-166

Sidhu J, Hanna J, Toze S (2008) Survival of enteric microorganisms on grass surfaces irrigated with treated effluent. Journal of Water and Health 6: 255-262

Statistical Package for the Social Sciences (SPSS) (2011) Guía para el análisis de datos. McGraw-Hill. Madrid.

World Health Organization (OMS) (2006) Directrices sanitarias sobre el uso de aguas residuales en agricultura y acuicultura, Suiza pp 778-790

Evaluación de los indicadores de contaminación fecal en suelos tratados con biosólidos para el cultivo de pasto

Resumen. Los países en vías de desarrollo enfrentan el reto de la gestión y disposición de los biosólidos resultantes del tratamiento de aguas residuales. Uno de los más importantes temas está relacionado con el máximo nivel de patógenos permitidos y el efecto que puedan causar en el ambiente y en la salud humana cuando este material es utilizado para uso agrícola. Con el objetivo de conocer el riesgo generado por este tipo de prácticas, evaluamos el comportamiento de los indicadores de contaminación fecal en un cultivo de pasto usado como alimento para ganado lechero. El área de estudio se dividió en dos parcelas: una experimental en la cual se aplicaron lodos diluidos y otra control sin aplicación de biosólidos. Se recolectaron muestras de suelo, pasto, aguas superficiales y subterráneas y se analizó la presencia de coliformes fecales, Salmonella spp., fagos somáticos y huevos de helminto. Las concentraciones encontradas tanto en la parcela experimental como en la control, presentan disminución de los indicadores bacterianos evaluados en suelo y bajas concentraciones en el agua superficial, subterránea y en pasto; mientras que los indicadores virales y parasitarios tienden a disminuir más lentamente. Los resultados muestran como este tipo de gestión del biosólido permite aprovechar sus beneficios como enmienda orgánica, disminuyendo el riesgo sanitario generado por la presencia de patógenos.

Palabras clave: biosólidos; enmienda orgánica; pastos; patógenos
Zaleski K, Josephson K, Gerba C, Pepper I (2005) Potential regrowth and recolonization of Salmonella and indicators in biosolid amended soil. Applied Environmental Microbiology 71: 3701-3708.

Zapata R, Peláez C, Campos C (2011) Evaluación del riesgo agronómico, ambiental y sanitario derivado de la aplicación directa de biosólidos para el cultivo de pastos en un agroecosistema de vocación lechera del Norte de Antioquia. Informe final EPM. 37.

Avaliação dos indicadores de contaminaçáo fecal em solos tratados com biosólidos para o cultivo do pasto

Resumo. Os países em vias de desenvolvimento enfrentam o desafio da gestão e disposição dos biosólidos resultantes do tratamento de águas residuais. Um dos mais importantes temas se relaciona com o nível máximo de patogénicos permitidos e o efeito que podem causar no ambiente e na saúde humana, quando este material é utilizado para o uso agrícola. Com o objetivo de conhecer o risco gerado por este tipo de praticas, avaliamos o comportamento dos indicadores de contaminação fecal num cultivo de pasto utilizado como alimento para o gado leiteiro. A área de estudo dividiu-se em duas partes: uma experimental, na qual se aplicaram lodos diluídos e outra sem aplicação de biosólidos. Se recolheram amostras de solo, pasto, águas superficiais e superficiais e subterrâneas, e se analisou a presença de coliformes fecais, Salmonella spp., fagos somáticos e ovos de helminto. As concentrações encontradas tanto na parte experimental como na de controlo, apresentam diminuição dos indicadores bacterianos avaliados no solo e baixas concentrações na água superficial, subterrânea e em pasto; enquanto os indicadores virais e parasitários tendem a diminuir mais lentamente. Os resultados mostram como este tipo de gestão de biosólidos permite aproveitar os benefícios como emenda orgânica, diminuindo o risco sanitário gerado pela presença de patogénicos.

Palavras-chave: biosólidos; emenda orgânica; pastos; patogénicos 